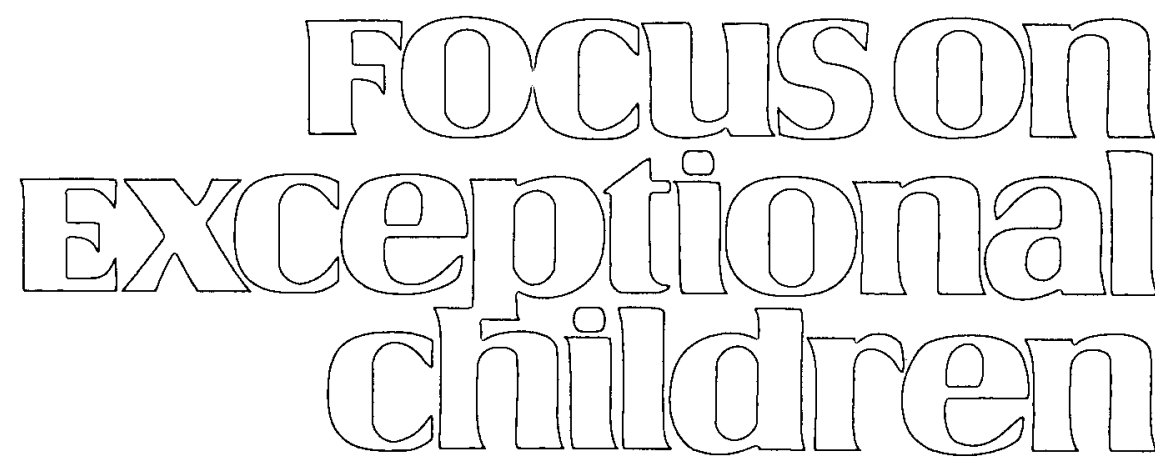

\title{
The Promise of Liberal Learning: Creating a Challenging Postsecondary Curriculum for Youth with Intellectual Disabilities
}

\author{
Stuart Z. Carroll, E. Richard Blumberg, and Jerry G. Petroff
}

Five years ago, a small group of higher education faculty at The College of New Jersey asked the question, "What would it look like if we created a postsecondary program for young adults with intellectual disabilities (ID) on the campus of a highly competitive four-year college?" Ultimately, our answer was that following the logic of normalization and inclusion, we should approximate the postsecondary experience of typically developing young men and women. We were aware of program models that were emerging in other places, but believed that our approach should reflect the characteristics of our existing campus and surrounding community. We had no idea how hard we would work, how much we would learn, and how many benefits would accrue to all the parties involved.

\section{THE COLLEGE OF NEW JERSEY}

The College of New Jersey (TCNJ), a state college located in suburban, central New Jersey, is primarily an undergraduate, residential school, with approximately 5,000 undergraduates and about 800 graduate students. Fully a quarter of the undergraduate students are in programs leading to teacher certification, and the remainder are in various arts, science, and professional schools. The mission statement of The College states, "The College prepares students to excel in their chosen fields and to create, preserve, and transmit knowledge, arts, and wisdom" (The College of New Jersey [TCNJ], 2007), and this belief is reflected in the number and rigor of liberal learning courses required of all students at The College.

TCNJ School of Education's conceptual framework calls for "creating agents of change" (TCNJ School of Education, p.1), and among its five core principles are demands that graduates demonstrate professionalism, advocacy, and leadership. TCNJ School of Education graduates are to "become future leaders advocating not only for the needs of children and youth in New Jersey but also for the educational profession at large" (TCNJ School of Education, p. 3). The combination of a strong commitment to liberal learning and to graduating education professionals who see themselves as change agents has made TCNJ an ideal venue for a program in which students with ID can learn about themselves and the world together with their age peers.

Drs. Jerry G. Petroff, E. Richard Blumberg, and Stuart Z. Carroll are all with The College of New Jersey. 


\section{A Different Kind of Transition Program}

In keeping with TCNJ's focus on a well-rounded education for all, we chose not to create a transition program with a narrow focus on housing and employment as is often the case in existing offerings for young adults. Rather, we hoped to create an inclusive community that could support young adults with disabilities through the developmental process of the transition to adulthood, and to offer them a content-rich liberal education that would support them as lifelong learners and as citizens. We believed that a college campus could serve as a supportive environment in which young adults could develop an understanding of themselves in the context of their peers, and through exposure to the various academic disciplines, develop the skills and dispositions necessary to become interdependent adults. We believed that participation in this kind of higher education could be as transformative for young adults with ID as we have seen it be for cohort after cohort of typically admitted college students.

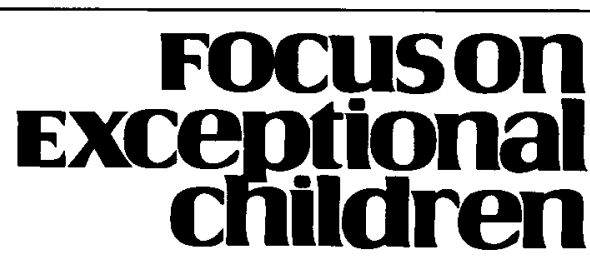

ISSN 0015-511X

FOCUS ON EXCEPTIONAL CHILDREN (USPS 203-360) is published monthly except June, July, and August as a service to teachers, special educators, curriculum specialists, administrators, and those concerned with the special education of exceptional children. This publication is annotated and indexed by the ERIC Clearinghouse on Handicapped and Gifted Children for publication in the monthly Current Index to Journals in Education (CIJE) and the quarterly index, Exceptional Children Education Resources (ECER). The full text of Focus on Exceptional Children is also available in the electronic versions of the Education Index. It is also available in microfilm from Serials Acquisitions, National Archive Publishing Company, P.O. Box 998, Ann Arbor, MI 48106-0998. Subscription rates: individual, $\$ 42$ per year; institutions, $\$ 56$ per year. Copyright $(\mathcal{O}) 2008$, Love Publishing Company. All rights reserved. Reproduction in whole or part without written permission is prohibited. Printed in the United States of America. Periodical postage is paid at Denver, Colorado. POSTMASTER: Send address changes to:

Love Publishing Company

Executive and Editorial Office P.O. Box 22353

Denver, Colorado 80222

Telephone (303) 221-7333

\section{EDITORIAL BOARD}

$\begin{array}{cc}\begin{array}{c}\text { Lisa Dieker } \\ \text { University of Central Florida }\end{array} & \begin{array}{c}\text { Paula Maccini } \\ \text { University of Maryland } \\ \text { Marleen Pugach }\end{array} \\ \text { University of Wisconsin-Milwaukee } \\ \begin{array}{cc}\text { Carrie E. Watterson } & \text { Stanley F. Love } \\ \text { Editor } & \text { Publisher } \\ \hline\end{array}\end{array}$

\section{DEVELOPING THE VISION}

One of our first steps in creating our program was to choose its name. We selected the name "Career and Community Studies (CCS)" because it sounded like the other academic programs and interdisciplinary majors on our campus, and reflected the content of the core curriculum we envisioned.

Our administration was highly supportive of this initiative, but insisted that we use the mission of The College as our guiding principle. This fit with our belief that any program we would create should approximate the college experience of other undergraduate students, and should be of benefit to the campus community as a whole. The program mission statement states that:

\begin{abstract}
The Mission of the Career and Community Studies (CCS) program is to provide a coordinated and comprehensive course of study that includes career exploration and preparation; self-awareness, discovery, and personal improvement, through a framework of liberal learning and community participation. (Career and Community Studies [CCS], 2006)
\end{abstract}

We articulated the following beliefs that would guide our process of program development and decision making:

- All youth go through a similar developmental process that requires certain activities, experiences, and supports.

- All youth must develop skills and understandings about themselves and the world around them, in order to fully participate in society and to become successful interdependent adults.

- Higher education has value as a vehicle for power and access to social networks and to cultural and social capital.

- Liberal learning promotes the development of critical thinking, self-reflection, and an understanding of the interrelatedness required for civic responsibility.

- Group membership provides essential motivation and support for learning and participation in community life. (CCS, 2006)

\section{LIBERAL LEARNING AND STUDENTS WITH ID}

The most recent public school reform initiatives maintain a central focus on meeting the social and academic needs of all students, including those with disabilities. As mandated by federal legislation such as the No Child Left Behind Act of 2001, schools are required to raise the bar for all students and give children and youth with ID the opportunity to reach higher levels of achievement in literacy and content knowledge. The inclusive education movement, fueled by the Individuals with Disabilities Education Improvement Act of 2004 (PL 108-446), has strongly encouraged school personnel to 
have high expectations for all students through the implementation of heterogeneous classrooms.

For inclusive education to achieve its desired objectives, educators must implement best practice in universal design for learning and implement strategies of differentiation. State core curriculum content standards must be the basis for the curriculum and assessment for every student, regardless of their abilities or labels. These dramatic changes in expectations for America's schools and students have presented both challenges and benefits.

As more and more students with ID benefit from more demanding programs in their public school experiences, it is not surprising that access to post-secondary education and its liberal arts curriculum has become the next frontier for inclusion. This demand could easily lead to the creation of a parallel postsecondary education system that would not provide equal access to the full benefits that college provides to typical students. By creating the CCS program, we hoped to avoid this.

TCNJ's CCS program is designed to provide a rich and rigorous academic course of study while supporting the psychosocial development of its students as they enter adulthood. Our goals for the students are that they leave college with access to entry-level jobs within careers of their choice, engage in adult relationships separate from their families, and be possessed of the tools needed to be optimally interdependent. Liberal arts education equips CCS students with skills of critical thinking, appreciation of diversity, and general knowledge of the arts and history of our civilization. It arouses students' curiosity about the world and enhances their ability to participate in our cultural conversations and to play an active role in addressing the questions and issues that face our community.

\section{Defining the Context of a Liberal Arts Education}

In 1998, the board of directors of the Association of American Colleges and Universities (AACU) adopted a "Statement on Liberal Learning" articulating the goals of liberal learning for all institutions of higher education. Liberal education is broadly understood as a "philosophy of education that empowers individuals with broad knowledge and transferable skills, and a strong sense of value, ethics, and civic engagement" (Association of American Colleges and Universities [AACU], 2006). While the curriculum of liberal education is often debated, there is general consensus that liberal learning is characterized by a strong focus on intellectual and scholarly growth, civic responsibility, and human inquiry (AACU, 1998; Laff, 2005; Lopatto, 2006). The end product of a liberal education is the creation of productive, responsible, and creative citizens who value the benefits of lifelong learning. It is this fundamental belief in the transformative nature of liberal studies that has shaped the early foundations of higher education and continues to inform the ongoing discussion on the benefits of liberal learning and the role of the university.

The making of productive, knowledgeable, and engaged citizens is a primary goal of liberal learning. Many universities are established with this basic civic mission to prepare students for active participation in our diverse and global society. As such, liberal learning encompasses both the production of knowledge and practical skills, as well as preparation for active participation in the community. It can be argued that in an egalitarian society, it is not possible to have one without the other. From this perspective, knowledge or skills alone are not sufficient to motivate or prepare people for productive lives in today's diverse society (Checkoway, 2001). This dual focus distinguishes liberal education from a purely vocational or skills-oriented learning experience. Additionally, Laff (2005) argues that the skills of liberal learning are inextricably connected to personal growth and human development. Thus, the benefits of liberal learning extend to both the individual and society, mutually reinforcing the growth of the other. Clearly, liberal learning is based on a well-established tradition and belief in the role of institutions of higher education in supporting the development of youth as productive and engaged citizens.

Liberal learning is also characterized as inclusive, global, and encompassing of all fields of study and all kinds of students. According to the AACU's "Statement on Liberal Learning," "the spirit and value of liberal learning are equally relevant to all forms of higher education and to all students" (1998). Liberal learning values diversity and recognizes the plurality of the human experience, yet, ironically, there is little in the literature that specifically examines the goals of liberal learning for students with disabilities, one aspect of student diversity.

This gap in the literature may flow from the low participation rate of students with disabilities in postsecondary settings and the near absence of students with ID on university and college campuses, the primary sites of liberal learning and liberal education. Approximately $6 \%$ of all youth with disabilities attend four-year colleges and universities compared to $28 \%$ of the general population (Wagner, Newman, Cameto, Garza, \& Levine, 2005). According to the most recent data from the second National Longitudinal Transition Study of postschool experiences for youth with disabilities, there are no students with intellectual disabilities enrolled in any four-year colleges and universities (Wagner et al., 2005). Concerns of equity and accessibility in higher education are not new, especially in regards to the underrepresentation of students from low socioeconomic backgrounds, and racial and ethnic minorities (Astin \& Oseguera, 2004), but students with disabilities remain a population to whom education is not equally available. 


\section{Choosing College as a Postsecondary Outcome for Students with ID}

Our belief that attending college and participating in a strong liberal arts curriculum may greatly benefit some youth with ID is based upon the documented positive effects of liberal learning on typically developing young adults. Although many of the benefits of liberal education have been asserted with less than empirical evidence, there are strong indications that there can be significant impacts on the personal and intellectual growth of young adults (Pascarella et al., 2005). In addition, some evidence seems to indicate that the social-psychological context provided within many liberal arts colleges has a further role in student success (Astin, 2000; Pascarella, 2001) and personal growth. As a result, the TCNJ CCS course of study has been designed to mirror the liberal arts education of typically enrolled students in the belief that this will result in further human growth in all developmental areas.

Although college-based programs have existed for some time (Neubert \& Moon, 2006), the notion that young adults with ID could benefit in the same ways as their peers without disabilities is a new one. The CCS program has been something of a laboratory for determining whether and how such an approach could succeed.

The emerging framework for this practice seems to include several strong indicators for success:

- Access to liberal learning within an inclusive setting must be anchored within a total program structure. A formal program with a clear goals and objectives and its own infrastructure can assist students with ID to be more genuinely included in the social and academic fabric of a college and eventually be able to access college programs on their own.

- Individual adaptations and curriculum modifications must initially emerge through the efforts of trained and experienced professors. This helps promote the specific needs of individual students as they move to less controlled classroom environments with inexperienced professors.

- Efforts in meaningful and rich higher-education experiences require a team of professors and staff that work collaboratively on behalf of each of the students who are involved.

\section{THE INITIAL CURRICULUM DEVELOPMENT PROCESS}

Our college implemented a pilot summer transition program on campus in the summer of 2004. The results of this experience were very encouraging, but at the time we lacked the resources to develop a full inclusive program for students with ID. Then in 2005 we became aware of a grant opportunity through the National Down Syndrome Society, for the development of postsecondary programs. We applied and were awarded a modest amount of support. That, together with in-kind contributions from our college, enabled us to get started.

We realized that for our program to be successful, we would need to have strong connections to our surrounding community. We developed an advisory committee composed of parents, secondary educators, community service providers, business persons, TCNJ students, faculty, and administration. The purpose of this committee was to help us to develop policies and procedures, identify resources, develop collaborative relationships, and communicate our activities to the surrounding community.

One of the first activities of the advisory committee was to decide whom the CCS program would serve, and how we would make admission decisions. We didn't want to exclude potential students solely on the basis of their academic performance, yet we understood that students would need a certain level of literacy skills to connect with college-level coursework. After many discussions, we decided to adopt the AAMR definition of Intellectual Disability as the primary determinant of eligibility, and developed a list of criteria we felt would help us to make admission decisions. Our initial admission criteria are described in figure 1.

Applicants must be between the ages of 18 and 25 at the start of the program.

$>$ Applicants must have a significant cognitive and/or developmental disability that interferes with their academic performances.

$>$ Applicants must have sufficient emotional and independent stability to adjust and participate in all aspects of the CCS coursework and campus environment.

$>$ Applicants must demonstrate the ability to accept and follow reasonable rules and behave respectfully towards others. Note: CCS does not have the personnel to supervise students with difficult and challenging behaviors or dispense medications.

$>$ Applicants must have a sincere desire to attend CCS.

$>$ Applicants must have the potential to successfully achieve their goals within the context of the CCS program.

> Applicants must have applied with the Division of Vocational Rehabilitation. 


\section{Designing the Curriculum}

The development of postsecondary curriculum for youth with ID is a relatively new challenge for educators. Neubert, Moon, Grigal, and Redd (2001) conducted a review of 27 published articles on postsecondary supports for students with intellectual disabilities from the 1970 s to 1990 s. They identified an interesting philosophical shift during these three decades, from a focus on the physical integration of adults with disabilities on college campuses in the 1970s to the provision of individualized supports for youth with disabilities (ages 18-21) in postsecondary settings by the end of the 1990s. Program models have primarily focused on employment and vocational training, with some interest in supporting social opportunities for students. Although these programs were housed on college campus, few supported any degree of inclusion into age-appropriate activities or college courses.

More recently, Hart and colleagues (2004) conducted a national survey of 25 postsecondary education programs that support youth with learning, cognitive, and intellectual disabilities. Their main findings indicate that most students are served in either mixed or substantially separate programs in postsecondary settings, which are primarily focused on functional life skills and employment training. Those students in the individualized, inclusive models, considered "innovative" programs, were provided with greater access to college courses, certificate programs or internships, including those available to the general student body. Many of these programs also had an employment or vocational training component (Hart et al., 2004; Hart et al., 2005).

The available literature suggests that of the few students with intellectual disabilities who are accessing postsecondary education, most are involved in programs focused on employment and life skills and predominantly housed within community colleges and vocational-technical schools. This is consistent with national data that indicates that students with disabilities are more likely to take classes at two-year colleges than any other form of postsecondary education (Wagner et al., 2005).

It was our intent to develop curricula that would challenge our students and motivate them to explore themselves and the world around them in ways they had not done previously. Looking back, we didn't really know what our students would be capable of (they are patiently teaching us each day). We conducted research into existing postsecondary program models and curricula, and reviewed the transition literature extensively. We found that there were not models that clearly described inclusive curricula based within a context of liberal learning. Once again, we returned to our mission statement and values to establish objectives that would guide the process of curriculum development.

Our guidelines were to make the program as inclusive as possible, to use universal design to make typical coursework accessible, and to provide reasonable accommodations where needed. We aimed to develop students' self-awareness and self-determination and to help them become connected to social networks and community resources. Ultimately we hoped to connect students to meaningful careers and satisfying lifestyles.

We made some assumptions about the nature of a comprehensive postsecondary curriculum for youth with ID that included the following understandings:

1. Students would need significant support (people, technology, and training) to participate in collegelevel coursework.

2. Students would need social support to become integrated within the community of our College.

3. Typical coursework would need significant modification.

4. Specialized coursework would need to be created to address functional knowledge and skills related to the typical transition domains (vocational/career exploration, independent living, social, and communication skills, etc.).

At the time of this writing, there are no curriculum or accreditation standards for postsecondary programs for students with ID. Our college did not have a mechanism for admitting the students we planned to serve through the usual admission process, but had a history of offering certificate programs. We decided to create a four-year certificate program in Career and Community Studies. Students are admitted to the certificate program, and have student IDs and access to all the resources and amenities of the campus.

In designing the CCS curriculum, we attempted to approximate the full-time program taken by typically admitted students. As in other departments, Career and Community Studies would offer core coursework, designed by the program faculty. In addition to core coursework, students would have the opportunity to attend typical college courses that reflected their individual interests. An example of the proposed certificate program is included in Table 1.

The CCS core coursework was developed to replicate the design of typical TCNJ courses. All courses have syllabi containing clear objectives, requirements, schedules, readings, and evaluation criteria. Students in the program are required to take all core coursework as members of a cohort. They attend their first inclusive classes (Freshman Seminar and Introduction to Educational Psychology) together as a cohort as well. In these courses, taught by CCS core faculty, CCS students are exposed to the organization and requirements of typical classes, and we are able to evaluate each student's academic performance and support needs. 
TABLE 1

CCS Coursework: Four-Year Sequence

\begin{tabular}{|c|c|c|c|}
\hline Freshman & Sophomore & Junior & Senior \\
\hline $\begin{array}{l}\text { Fall Term } \\
\text { Planning Forum } 101 \\
\text { Career Exploration } 101 \\
\text { Personal Exploration } 101 \\
\text { Freshman Seminar FSP } \\
\quad 121\end{array}$ & $\begin{array}{l}\text { Fall Term } \\
\text { Planning Forum } 201 \\
\text { Great Conversations } 201 \\
\text { Consumer Math } 201 \\
\text { Assistive Tech } 210 \\
\text { Inclusive Course TBD } \\
\text { Internship 201 }\end{array}$ & $\begin{array}{l}\text { Fall Term } \\
\text { Planning Forum } 301 \\
\text { Internship 301a } \\
\text { Inclusive Course TBD } \\
\text { Transition Education \& } \\
\text { CBI SPED } 631\end{array}$ & $\begin{array}{l}\text { Fall Term } \\
\text { Planning Forum } 401 \\
\text { Inclusive Course TBD } \\
\text { Senior Seminar: Portfolio } \\
\text { Development } \\
\text { Internship } 401\end{array}$ \\
\hline $\begin{array}{l}\text { Spring Term } \\
\text { Writing Tech. \& Strate- } \\
\text { gies } 101 \\
\text { Planning Forum } 102 \\
\text { Career Exploration } 102 \\
\text { Assistive Technology } 101 \\
\text { Great Conversations } \\
\text { Child/Adolescent Devel- } \\
\text { opment SPE } 203\end{array}$ & $\begin{array}{l}\text { Spring Term } \\
\text { Planning Forum } 202 \\
\text { Personal Finance } 202 \\
\text { Health \& Wellness } 202 \\
\text { The Finer Things } \\
\text { Inclusive Course TBD } \\
\text { Internship } 201\end{array}$ & $\begin{array}{l}\text { Spring Term } \\
\text { Planning Forum } 302 \\
\text { Inclusive Course TBD } \\
\text { Internship } 302\end{array}$ & $\begin{array}{l}\text { Spring Term } \\
\text { Planning Forum } 402 \\
\text { Inclusive Course TBD } \\
\text { Senior Seminar } \\
\text { Internship } 402\end{array}$ \\
\hline $\begin{array}{l}\text { Summer Term } \\
\text { Collaboration EDUC } 513 \\
\text { Building Relationships } \\
\quad 101 \\
\text { Campus Rec. } 103 \\
\text { Community Leisure } 101\end{array}$ & $\begin{array}{l}\text { Summer Term } \\
\text { Building Relationships } \\
201 \\
\text { Campus Rec. } 203 \\
\text { Comm. Leisure } 201 \\
\text { Internship 201c }\end{array}$ & $\begin{array}{l}\text { Summer Term } \\
\text { Community Living } 301 \\
\text { Inclusive Course TBD } \\
\text { Internship 302c }\end{array}$ & $\frac{\text { Summer Term }}{\text { Internship 402c }}$ \\
\hline
\end{tabular}

The freshman year of the CCS program is intended to serve as:

1. an assessment of the student's interests, preferences, and support needs;

2. orientation to the campus, social activities, and clubs;

3. training in the skills needed to be a successful college student (organization, time management, social skills, and access to and use of campus resources);

4. use of mentor support and assistive technology; and

5. development of an initial plan for completing the certificate program (courses to be taken and other learning activities to be pursued).

Students typically begin to select their own classes from the course catalogue beginning in their sophomore year. Students attend these classes with mentor support. CCS program staff work with individual course instructors to design adaptations and accommodations. In some cases, little adaptation is needed, and mentors fade their support quickly. In other cases, mentor support is ongoing and CCS program staff significantly adapt course requirements and assessments.

During four years of program participation, CCS students develop an electronic portfolio of their best work. The portfolio is a collection of permanent products that demonstrates a student's learning in a variety of formats. Students may elect to use written products, audio/video recordings, visual representations, and artifacts articles, brochures, etc.). Student portfolios are evaluated by a faculty committee using standard criteria (a rubric). In addition, students receive a transcript of their grades and credits earned toward completion of the certificate program.

We anticipate that the success of the CCS program will be judged by the outcomes our students achieve after completing their program (employment, independent living, community participation, social relationships, etc.). For this reason, students begin to participate in work experiences as early as the spring of their freshman year. These work experiences reflect their individual interests and abilities. They include part-time unpaid work in the library, various campus 
offices, the gym, bookstore, and information technology. These initial work experiences, usually about four hours a week, enable students to sample various work environments and tasks on the college campus. The program is designed so that by the senior year students are prepared to conduct a year-long internship in a competitive employment situation in the community.

Core coursework, taken across the four years of study, prepares students for careers, independent living, community participation, civic engagement, the development of social networks and intimate relationships. The college environment serves as a natural setting in which important career and social skills are learned, and relationships established. Through relationships with mentors and participation in campus clubs and social activities, students develop social competence and self-esteem.

These benefits have arisen in the context of carefully designed inclusive experiences. In the next section we describe three inclusive courses in some detail.

\section{CCS APPROACHES TO POSTSECONDARY INCLUSION}

As we have indicated, students in the CCS program participate in a number of different courses with other college students. They first do so as members of the CCS cohort, in classes that are specifically structured to be inclusive experiences; then they subsequently choose individual college courses and receive faculty, peer, and program supports that vary according to the context.

Faculty who work with the CCS program have developed and implemented three specific courses to provide liberal learning within an inclusive setting and introduce freshman and sophomore CCS students to the college experience. Our experience with each of these courses has been highly positive, and we believe that they suggest models for how students with intellectual disabilities can: (1) be provided with meaningful instruction in the liberal arts/humanities; (2) become part of the social and academic fabric of the student body; and (3) be prepared for successful integration into a variety of courses across the seven schools within The College. We next detail these approaches and include initial data that supports their promise as methods of inclusion in higher education.

\section{Human Abilities: Unplugged-A Freshmen Seminar}

Human Abilities: Unplugged is one of more than 80 courses that incoming TCNJ freshmen can choose to take in their first semester of study at The College. The course looks at disability as a key aspect of the human experience and explores it through an alternate post-modern paradigm that views difference from a variety of angles. The course commences and terminates with an attempt to define "human-ness" and the parameters of what makes us human. Students explore models and theories that examine social, political, cultural, and economic factors that define disability and help determine personal and collective responses to difference. At the same time, coursework focuses on de-stigmatizing disease, illness, and impairment.

The course has a number of unique features, the chief one being the inclusion of all 6 to 8 first-year CCS students together with 12 to 15 typical TCNJ freshmen. The seminar uses universal curriculum and instructional design to ensure that all students are provided with a rigorous course that includes significant writing, reading, and discussion. At the start of the course, students are organized in small groups of 4 or 5 , which are heterogeneous by gender, major, and disability. These groups are maintained throughout the semester in order to develop relationships among group members and nurture the individual strengths of participants. Discussions, activities, and outside-of-class assignments are completed within these groups.

The class is designed to make complex course material accessible to all students. For example, the student groups are given responsibility for outlining text chapters and identifying three to five "big ideas" and concepts. The instructor meets with the groups to suggest modifications and improvements; then these outlines are posted on the course website where they can be used by all students to study or review.

An accepted tenet of universal design is that there should be a variety of ways in which content is represented (Spooner et al., 2007). In the Human Abilities: Unplugged course, in addition to reading and attending lectures, students are required to view approximately a dozen contemporary films that address specific areas of disability study. Student groups are responsible to facilitate a full class discussion of a film and to make connections to course texts. For example, the French film, The 8th Day (1997) is required as a companion to lectures and guest speakers addressing institutionalization of people with intellectual disabilities.

In order to make class lectures and readings more accessible, the course instructor, program staff members, or peer mentors conduct pre-teaching sessions focused on the main ideas to be covered in class. This enables CCS students to participate more actively in class and to make contributions that are valued by all.

The course deals with significant and controversial issues that require students to work out their own values and beliefs as they consider multiple perspectives on highly charged topics. In considering such matters as the political, social, and economic forces that shape societies' understandings of disability, students develop their analytical and critical thinking skills, key components of a liberal education. Topics such as the rights of people with disabilities are of immediate concern 
to the CCS students, so their engagement and motivation are maximized. This is consistent with a second key component of universal design, the need to engage all students intellectually and emotionally (Spooner et al., 2007).

Another valuable inclusive assignment in this seminar course is the life history interview, in which the student groups conduct and interpret interviews of adults with disabilities. The professor instructs the group on basic methodology of ethnographic interview research and the class establishes a generic interview protocol to be used in the project. Each group then conducts an in-depth interview. The oral histories for the past two years are currently being formatted to be archived on a TCNJ college website in a collection called The Human Abilities Project (HAP). The data from the oral histories will be used as texts to be analyzed as part of the course in future years.

The seminar culminates with field trips that reflect the overall theme of the course, which is the variance of human ability. The first seminar visits an integrated studio and gallery in New York City that represents artists with autism and other developmental disabilities. This year's class also participated in the New York premiere of a documentary film addressing the current abuse of people with developmental disabilities in institutions in Texas.

During the first year of the seminar, a psychology student worked with the professor to document each class in a participatory research initiative. She took extensive field notes focusing on the inclusion of the students with disabilities within the class; the social acceptance of the students without disabilities; and evidence of the use and success of universal design for learning. We are currently conducting a content analysis of this data, and also looking at results of focus group conversations conducted after the second year of the course. Though our findings are preliminary, there are strong themes that have emerged:

- Each of the students with ID evolved socially and academically during the course, as evidenced by increased class participation and the assumption of greater roles within the small groups.

- Students without disabilities came to rely more on the CCS students in group work and became more respectful of their role and status in the class.

- There was little to no role for CCS mentors in the class because the professor implemented a universal approach to course design.

- CCS students became less a group to themselves and were more integrated within the fabric of the class. This was most evident in the way that small groups functioned outside of class.

- Typical students displayed greater comfort with the artifacts of disability such as self-stimulatory behavior or differing communication abilities among the CCS students.

We believe that the experience for the students with ID clearly assisted them in their acclimation to college and reinforced the potential in each of them. As one student stated, "I know things and words that I never thought I could understand, and I want to know more."

\section{The Psychological Development of Children and Adolescents}

SPE 203, the Psychological Development of Children and Adolescents, is an introduction to educational psychology. This course meets an undergraduate social and behavioral sciences requirement, and draws students from a variety of academic majors. Through lectures, discussions, films, and group activities, the course explores the psychological development of children and adolescents. Course assignments require students to apply development theories and current research to the assessment of learning problems in children and youth.

As with any introductory course that surveys prominent theorists, developmental theory, and applied methodologies, this course runs the risk of overwhelming students with information of questionable relevance. For this reason, course instructors strive to connect the material to the individual, lived experience of students, and the solution of meaningful problems. Over the years that we have taught the course, the most successful classes have been the ones in which student interactions led participants to make important personal discoveries.

Because of its content and design, SPE 203 seemed an appropriate inclusive experience for students in the CCS Program. Current thinking about intellectual functioning has focused upon the ability of individuals to create ideas from lived experience, to reflect upon the ideas, and understand them in the context of other ideas (Greenspan, 1997). Students with ID, like other TCNJ undergraduates, have had recent experiences as children and adolescents. It was our hope that within the context of the course and with peers of similar ages, these experiences could be explored and connected to developmental theory in a meaningful way. We assumed that with adaptation of instruction and evaluation, and given reasonable accommodations, for example, mentor support and technology, the CCS students could be successfully included in the course.

One of the initial considerations in developing any inclusive learning experience is how the instructor addresses real issues of student learning differences. The instructor may choose to allow these differences to emerge during the course of instruction and address them in real time, or the instructor may decide to prepare students for what they may 
experience with information that explains anticipated differences in learning or behavior. We chose to adopt a mixed approach in developing the inclusive process of SPE 203.

To prepare the students with ID for the course, we conducted pre-teaching sessions prior to each class session, assisted by student mentors. Initial sessions, held before the course began, focused primarily on appropriate social behaviors expected of all students in the course, with role play to reinforce understanding and skill acquisition. In addition, the learning objectives and academic requirements of the course were discussed, with particular attention given to the adaptations and accommodations available to CCS students.

On the first day of class, the CCS students were included in the course with their typical peers, without any extraordinary introduction. All students were divided into working groups, using a strategy that ensured that the CCS students were evenly distributed among the groups. An icebreaker activity was used to introduce group members to each other, and the learning experience of SPE 203 had begun.

The Psychological Development of Children and Adolescents uses printed material including the text Educational Psychology (Woollfolk, 2007), lecture notes, and supplemental readings. Prior to each class session, the CCS students were pre-taught the content by reviewing the "big ideas" contained in the lecture notes. For example, in preparing students to learn about Vygotsky's socio-cultural theory, the big ideas were presented in the following ways:

1. Human activity takes place in cultural settings and can't be understood apart from them.

2. Learning is co-constructed with others.

3. Development is the transformation of shared activities into internalized processes.

In addition, concepts such as cultural tools, scaffolding, and the zone of proximal development were explained. These big ideas were reinforced by examples provided by the instructor, and then students were asked to provide their own meaningful examples. In addition, students were pre-taught the objectives and processes of any group activities planned for that class session, and were given an opportunity to discuss assignments, supplementary readings, or films.

The result of these pre-teaching sessions was that the CCS students were consistently well prepared to participate in class discussions and activities. In fact, they were typically among the first students to respond to probing questions from the instructor, and often provided cogent and moving examples of life experiences or observations relating to concepts and methodology. Over time, most were active participants in group work, and shared the responsibility of "reporting back" the group's product to the whole class.
In addition to the pre-teaching sessions, CCS students had the use of mentors to work with them daily during scheduled study periods. These mentors would discuss the readings with them, review the big ideas, help with homework assignments, prepare for tests, etc. CCS students were given adapted tests, with fewer items to respond to. These items related to the big Ideas, and were both multiple choice and brief answer. Students were allowed to refer to their lecture notes in their responses to test items. All test items were taken verbatim from the nonadapted test given to the whole class.

The culminating learning activity for SPE 203 is the virtual student case study project. This is a group assignment that requires students to critically analyze and apply course content in assessing and responding to the learning challenges of a virtual student whose profile they have been given. The group is required to prepare a written product containing a student profile, assessment report, and support plan, and a presentation of their work to be shared with the whole class.

The virtual student project requires students to identify and share the tasks involved in creating the assigned products. These include research, writing, presentation development, and presentation. This is perhaps the most challenging aspect of the inclusive experience for all students in the class. To ensure the success of the group process, the instructor schedules times throughout the semester to meet with each group to monitor their progress. At first, some of the typical students struggled with how much responsibility to give the students with disabilities. However, provided the out-of-class support of mentors, the students with disabilities were able to contribute to all project development activities. The success of the projects was apparent at the time of group presentations. The CCS students participated equally with their typical peers, and in a few cases, seemed more comfortable than their group mates.

All of the students with ID passed the course. They were evaluated using the same criteria applied to other students: the quality of their participation, test scores, and the virtual student project. The adaptations and accommodations provided seemed to be sufficient to enable them to be successful in the course.

End of semester course evaluations revealed that the typical students were comfortable with the inclusive nature of the course. Some students expressed initial discomfort, but all stated that this was replaced over time with an appreciation for the contributions of the CCS students. Many student comments stated that the presence of students with intellectual disabilities enriched the learning experience for them.

The course instructor found that the inclusion of students with ID in a typical undergraduate course forced him to reflect on his learning objectives for all students, and to differentiate instructional approaches in ways that enriched the 
teaching experience. The adaptations that were made to instruction and evaluation of student learning were efficient in terms of time and effort. The weekly pre-teaching (30-45 minutes per class) required additional faculty teaching time initially, but was soon transferred to undergraduate student mentors. The CCS program provided mentor and technology support outside of class that was essential to student success.

\section{Great Conversations}

A core belief of the CCS program is that its students have a right to be exposed to challenging content in a range of academic disciplines and to develop "critical thinking, selfreflection, and an understanding of the inter-relatedness required for civic responsibility" (CCS Core Beliefs). We hope to achieve this by having students audit a range of regular college courses, but we have also seen a need to create a course that would expose the CCS students to numerous college subjects and involve them in academic interactions with their typical peers. We named this course Great Conversations (GC), because it is intended both to expose all participants to the conversations that animate the academic disciplines and also to give participants opportunities to talk to one another about these important questions.

The guiding principles of the GC course that emerged were that it would engage participants in the discourse and essential questions of the disciplines explored, increase general academic proficiencies such as writing, speaking, reading, and critical thinking, and provide an inclusive learning experience in which CCS and typical college students would all increase content knowledge and academic skills.

The semester-long GC course is organized into six or seven two-week modules, each of which deals with a different academic content area. The class meets twice a week for an hour and twenty-minute session each time, and CCS students are given additional support before and after class sessions to maximize the quality of their participation and learning. Each module considers two or three core questions in its discipline and exposes students to the ways of thinking and forms of discourse that characterize the area.

Originally our intention was that each course module would be designed and delivered by a faculty member, but as the course evolved we invited graduate students and upper-class undergraduates to participate in curriculum development and delivery, with close supervision from faculty and staff associated with the CCS program. We briefed all module designers on the course context and assisted them in designing exemplary inclusive lessons and modules.

The modular design of the course has allowed us to cover a range of topics in the hard sciences, social sciences, humanities, and fine arts, and has enabled us to involve a range of college faculty, students, and staff in curriculum design and delivery. It has also made it possible for us to involve typical TCNJ students as learners in the class. Because the course is not credit bearing for them, we felt that we would have more success getting them to commit to attend for two weeks rather than a full semester, and were in fact able to recruit students in a number of different ways; some took the class to fulfill a service requirement, others used it to complete a project in another course, and still others attended out of sheer curiosity. As a result of our recruitment efforts a typical GC lesson has 12 to 15 TCNJ students learning alongside the $6 \mathrm{CCS}$ students.

Because the group of TCNJ students varies from lesson to lesson, it has been necessary to review extensively at the start of each Great Conversations class. This actually became a strength of the modules as main themes and ideas were repeated. Similarly, we have felt a need to start nearly every lesson with an icebreaker activity, which has had the effect of increasing interaction between the CCS and typical students and helped to create a positive classroom climate.

A particularly successful module was one on sensory perception, designed by Sean MacAneny, a graduate special education major. The module began with a simulation in which students acted out the interactions of the brain and nervous system. Subsequent lessons examined issues with each of the senses, including an activity demonstrating the extent to which the senses of sight and touch function together, and one in which perfumes were analyzed to see whether there was any real difference between scents intended for male or female audiences or if the distinctions were purely a function of marketing. The final lesson included a mirror-image maze which demonstrated how the senses could be deceived, and in which CCS students were often more successful than the others. Mini-lectures were interspersed with well-designed activities and small group discussions.

On the whole the modules have been intellectually challenging, interesting, and inclusive. Not all modules have been equally successful, however, and we have greatly increased our knowledge and understanding of what can work in this type of postsecondary setting. Some of the guidelines we now give instructors are:

- Start every class with an icebreaker activity relevant to the content. For example, a poetry lesson could begin with students in small groups making rhyming couplets with their names.

- Put the students into mixed ability groups from the start of the lesson and give the groups time to process material presented throughout the lesson.

- If groups are to work with written text during the lesson, it should be brief and relatively simple.

- Avoid whole group discussion until small groups have addressed a topic. 
- Give students a chance to prepare answers to questions in advance, preferably in pairs or small groups.

- Ask intriguing, open-ended questions that everyone will want to answer.

- Use experiential and simulation activities where appropriate.

- Revisit the essential questions in each class. If possible, have a written chart or framework for students.

CCS students have told us that they enjoy the content they have studied and the interactions they have had with other TCNJ students in the class. All six CCS sophomores indicated that the class opened doors for them and introduced them to topics and issues that they would not otherwise have encountered. One student can remember all of the names of the chemicals we tested for in the water quality lessons. Another student did a presentation about an intellectual passion and chose poetry as his topic, using several poems from the previous semester's poetry module as examples.

Most intriguing to us is that the CCS students view GC as a real college course intended for all its participants, and not as something designed especially for them. When we asked them what they liked best about the course, one student replied that it was great for students to be exposed to different subjects. We thought she was referring to the CCS students, but she went on, "A Special Ed major might never have taken a chemistry class, but when they take it in Great Conversations they may realize they like it." Her perception of the Special Education major as a full student in the class was evidence to us that the course has succeeded as an inclusive experience.

The success of the Great Conversations experience has led us to offer a second semester of it to first semester sophomores, and to create the arts-based The Finer Things course on a similar model for second semester sophomores.

\section{MORE THAN MENTORS}

As college faculty, we like to think that our coursework is interesting, relevant, and useful to our students in their pursuit of careers and satisfying lifestyles. In the time they spend with us, we hope to give them the knowledge and skills they will need to be successful, interdependent adults.

Early in the development of the CCS program, we shared a commitment to facilitating social learning and academic support through the use of peer mentors. This made sense to us, because we needed to rely on mentors to supplement program staffing, and because we saw mentors as the key to the full and meaningful inclusion of students with ID on our campus. Mentoring relationships have been shown to enhance career, social, and emotional development (Kram, 1985; Kram \& Isabella, 1985; Mertz, 2001). However, mentoring is used broadly and there is some confusion about what the term means (Hurley, 1988). A review of the literature reveals that mentors provide a variety of useful functions including social/emotional support, role modeling, skill acquisition, information, and advice. Peer-mentor relationships provide both instrumental and emotional support. Instrumental support involves information about how to do something as well as assistance in completing a difficult task. Emotional support may involve modeling and teaching problem-solving strategies and ways to express or manage difficult feelings (Hagner, 2000; Kram \& Isabella, 1985).

We felt confident that the potential benefits of mentoring for students with ID in the CCS program would be many. We were also intrigued by the mutually enhancing benefits of the mentoring relationship we had seen documented in the literature, and wondered what the experience of being a mentor would do to enhance the learning and development of typically admitted students.

The More Than Mentors program was established within the Career and Community Studies program to provide students with ID academic and social support. Initially, peer mentors were recruited through undergraduate and graduate courses offered in the school of education, and through flyers posted throughout the education building. Mentors were asked to complete an application, and were interviewed by program staff. Peer mentors were provided with an orientation to mentoring; given an overview of the goals, services, and structure of the CCS program; and were introduced to the students. Peer mentors attended CCS core courses and accompanied CCS students during lunch and social-recreational activities.

At first the response to our mentor recruitment efforts was modest, yielding less than a dozen peer mentors who volunteered a few hours of their time each week. By the end of the first year of the program, more than 50 students from across departments within the college had volunteered to serve as mentors.

During our second year, more than 50 undergraduate and graduate students have served as peer mentors. In addition to our initial methods of recruiting mentors, we have found that mentors are effectively recruited via such student associations as Best Buddies, sororities, sports teams, clubs such as Anime; through departmentally required internships; through CCS-sponsored social activities such as our annual "poetry slam"; through incidental social interaction and word of mouth. Specially designed inclusive courses such as Great Conversations and The Finer Things have created comfortable and interesting vehicles for shared learning and the development of meaningful social relationships between students with disabilities and their nondisabled peers.

Each semester we conduct evaluations of the More than Mentors program. These evaluations have helped us to learn 
about the meaning and value of peer mentoring for typically admitted students, and we have used evaluation data to improve the design and quality of the More than Mentors program.

Some of the effects of peer mentoring that have emerged from our mentor evaluation data include:

1. mentors gaining an appreciation of students with intellectual disabilities as capable of participating in and benefiting from postsecondary education;

2. mentors gaining an understanding of the mentor role and seeing themselves as effective mentors;

3. mentors learning about disability and effective instruction and support; and

4. mentors developing satisfying relationships with students with intellectual disabilities.

We are currently conducting an in-depth study of the effects of peer mentoring on students who serve as mentors. We are continually evaluating the type, amount, and quality of support that mentors provide. Our future research will also investigate the effects of mentoring from the perspective of students with disabilities. Evaluation data and our ongoing observations suggest that peer mentors provide both instrumental and emotional supports that have assisted our students with intellectual disabilities to become academically successful in college coursework and socially integrated within the fabric of campus life. With varying levels of mentor support, students with ID are successfully completing specialized and typical/inclusive coursework; participating in campus organizations, clubs, and activities.

The success of students with intellectual disabilities in postsecondary education requires a collaborative effort among faculty, students, administration, families, and community resources. We are learning that creating an inclusive campus community is a complex, time- and labor-intensive activity. However, based upon our experience thus far, we believe the benefits of this endeavor are worth the effort, and that the transition of students with ID to meaningful and valued adult roles can be effectively facilitated by colleges and universities.

\section{REFERENCES}

Astin, A. (2000). How the liberal arts college affects students. In S. G. Koblik \& S. R. Graubard (Eds.), Distinctively American: The residential liberal arts colleges (pp. 77-100). New Brunswick, NJ: Transaction Publishers.

Astin, A. W., \& Oseguera, L. (2004). The declining "equity" of American higher education. The Review of Higher Education, 27 (3), $321-341$.

Association of American Colleges and Universities (AACU). (1998). Statement of liberal learning. Retricved January 4, 2008, from http://www.aacu.org/About/statements/liberal_learning.cfm.
Career and Community Studies (CCS).(2006). We believe that.. Retrieved January 4, 2008, from http://www.tcnj.edu/ ccs.

Greenspan, S. (1997). The growth of the mind: And the endangered origins of intelligence. Cambridge, MA: Perseus Books.

Hart, D., Mele-McCarthy, J., Pasternack, R. H., Zimbrich, K., \& Parker, D. R. (2004). Community college: A pathway to success for youth with learning, cognitive, and intellectual disabilities in secondary settings. Education and Training in Developmental Disabilities, 39(1), 54-66.

Hart, D., Zimbrich, K., \& Parker, D. (2005). Dual enrollment as a postsecondary education option for students with intellectual disabilities. In E. E. Getzel, \& P. Wehman (Eds.), Going to college: Expanding opportunities for people with disabilities (pp. 253-267). Baltimore, MD: Paul H. Brookes.

Hurley, D. (1988, May). The Mentoring Mystique. Psychology Today, 22(5), 38, 42-44.

Individuals with Disabilities Education Improvement Act of 2004, PL 108-146, 20 U.S.C. $\$ 1400$ et seq.

Kram, K. E. (1985). Mentoring at work: Developmental relationships in organizational life. Glenview, IL: Scott,.Foreman and Company.

Kram, K. E. \& Isabella, L. A. Mentoring alternatives: The role of peer relationships in career development. Academy of Management Journal, 28(1), 110-132.

Laff, N. S. (2005). Setting the stage for identity, learning, and the liberal arts. New Directions for Teaching and Learning, 103, 3-21.

Mertz, N.T. (2001, April). Unraveling the definitional threads: Mentoring and the academe. Paper presented at the annual meeting of the American Educational Research Association, Seattle, WA.

Neubert, D. A., Moon, M. S., Grigal, M., \& Redd, V. (2001). Postsecondary educational practices for individuals with mental retardation and other significant disabilities: A review of the literature. Journal of Vocational Rehabilitation, 16, 155-168.

Neubert, D. A. \& Moon, M. S. (2006). Postsecondary settings and transition services for students with intellectual disabilities: Models and research. Focus on Exceptional Children, 39, (4).

No Child Left Behind Act of 2001, PL 107-1 10, 115 Stat. 1425, 20 U.S.C. $\$ 6301$ et seq.

Pascarella, E. T., \& Terenzini, P. T. (2005). How college affects students: A third decade of research (Vol. 2). San Francisco: JosseyBass.

Pascarella, E. T., Wolniak, G. C., Seifert, T. A. D., Cruce, TY M., \& Blaich, C. F. (2005). Liberal arts colleges and liberal arts education: New evidence on impacts: ASHE higher education report. San Francisco: Jossey-Bass.

Spooner, R., Baker, J. N., Harris, A. A., Ahlgrim-Delzell, L., \& Browder, D. (2007). Effects of training in universal design for learning on lesson plan development. Remedial and Special Education $28(2), 108-116$.

The College of New Jersey (TCNJ). (2007). Mission statement. Retrieved January 4, 2008 from http://www.tcnj.edu/ ccr/about/ beliefs.

Wagner, M., Newman, L., Cameto, R., Garza, N., \& Levine, P. (2005). After high school: A first look at the postschool experiences of youth with disabilities: A report from the national longitudinal transition study-2 (NLTS2). Menlo Park, CA: SRI International. Available at www.nlts2.org/reports/2005_04/nlts2_report_2005 _04complete.pdf.

Woolfolk, A. (2007). Educational psychology (10th ed.). Boston: Allyn \& Bacon. 
Copyright of Focus on Exceptional Children is the property of Love Publishing Company and its content may not be copied or emailed to multiple sites or posted to a listserv without the copyright holder's express written permission. However, users may print, download, or email articles for individual use. 